\title{
Aggressiveness and Expressiveness as a Language Strategy in Political Discourse
}

\author{
Zdenka Kumorová
}

\begin{abstract}
In regards to ethnic and social stratification, the Slovak Republic is among the diversified countries and this stimulates cultural-social, economic, linguistic or ethnic discourses in society. These stimuli are being noticed by several political subjects of the extreme right and these subjects then present them through radical expressive means. These usually surprise the recipient by their exaggerated catastrophic scenarios about the state of the country or captivate the addressee by the attempt of right-wing populists to save the country or to mobilize the party against the threat. The aim of such expressions is to arouse negative as well as positive emotions in the recipient, which means that radical language strikes at the lowest human urges. It is a typical tool of right-wing populists which is characterized by several language strategies and its aim is to draw attention to a given political party. The interest of the addressee in populist rhetoric intensifies due to the simplicity of the language which provides space for an easy interpretation of the message by a wide spectrum of the public of various age and education levels.
\end{abstract}

Index Terms-Right-wing populist, language strategy, expressive means.

\section{INTRODUCTION}

Parties representing right-wing populism have had their own place in Europe and their existence has been accompanied by long traditions. It either weakens or intensifies through times of their presence in current political events. The term right-wing populism or the synonym "populist radical right" is defined by co-authors as "a narrowly conceived ideology based on which society is divided into two main homogenic groups of 'the righteous' and 'the corrupted' (e.g. the division into the righteous citizens and the corrupted elite or the righteous nation and the hostile minorities, etc.)" [1].

Based on the definition, there are two parties in Slovakia which may be labeled as right-wing populist parties: L'udová strana Naše Slovensko (People's Party Our Slovakia, LSNS) and Slovesnká národná strana (Slovak National Party, SNS). This study, however, analyses the language of the LSNS party only.

\section{CURRENT STUdY}

The media world is a rich source of a large number of representative materials with radicalized language content such as party election programs, promotional texts in the

Manuscript received August 2, 2019; revised September 17, 2019.

Zdenka Kumorová is with the Department of Slovak Language and Literature at Faculty of Arts of University Ss. Cyril and Methodius, Trnava , Slovakia (e-mail: zdenka.kumorova@ucm.sk). form of printed or electronic leaflets, large scale billboards, election posters, web page texts, social media texts, and Facebook texts in particular. The collection of this research material posed no problem at all as it exists in electronic form and is readily available on the Internet. Other materials were photographed, mainly billboards and posters left over from past elections. The collection of materials was also executed by means of contacting particular political parties. These were consequently digitized and formed the textual corpus differentiated based on the type of text and geographic and time origin. This specific corpus was analyzed from several linguistic points of view, the specific lexis of each text represented our primary interest as metaphorization of messages is a typical sign of texts that are suppose to attract large number of people. From a methodological point of view, we analyzed texts by sorting the lexis according to thematic affiliation and pragmatic function of words, the morphologic affiliation with a given part of speech was important as well. Expressivity of the text is secured by emotionally charged (non-neutral) words with positive or negative meaning which, as we supposed, are frequently used in the radicalized language of a right-wing populist political party. These words are very effective in a targeted propagandistic communication. They are sometime called flag or stigmatizing words. The results of analytical interpretations point to specific argumentative patterns of the analyzed political party which exhibit a high degree of aggression, targetting dissatisfied persons whose frustration stems from long term social-economic injustice and inequality. This is an area that is seen by the politicians of right-wing populism as having a large potential for fulfilling their own interests and the interests of their political party. In their speeches, however, they declare that their main goal is to defend the interests of Slovak nationals. Evaluating emotionality of the language effecting the addressee's emotions is the means for propagandistic persuasion of their own agenda and where the reason is diplomatically pushed aside, there is no space for searching for a standard consensus in the interests of the majority. J. Hasil suggests that "emotionality stands in opposition to any formality, including a linguistic one" [2]. This type of rhetoric attracts people who do not verify the authenticity of fabricated and emotionally charged information; they become easily influenced and manipulated by extreme populists whose main intention is to strengthen their own economic and power status in politics. An emotional-expressive lexis with a negative evaluating undertone pushes aside a formal neutral lexis from radicalized political speech and it becomes blunt, offensive and inconsiderate, lacking basic signs of decency and compromise. The hallmark of political speech bearing signs 
of representativeness, publicity and formality has disappeared; it is, to a certain degree, connected with the relaxed, post-modernist communication in media where the borders between public and non-public ways of expressing oneself are disappearing. The tabloids choose informal, spontaneous ways of communicating full of charged expressions with frequently subjective messages. From the point of view of expressiveness, the discourse of populist parties oscillates on the axis of formal - informal, public private. In public speech, the conveyed content projects not only the cognitive meaning, but also the evaluating semantic attributes - evaluating words that represent the evaluating attitude and emotional evaluating relationship to the labeled entity based on its value characteristics or parameters (compare Dolník, [3], Orgoňová, Bohunická, [4]). An expressive-emotional lexis with a negative undertone seems to be an effective communication tool for provoking fear of a frequently fictional enemy [5]. In addition to analyzing the tool itself, we need to draw attention to the language of extremism in a wider context - in political discourse which is characterized by its intentionality, that is, the ability to influence and persuade the addressee. The interpretation of the language of populism is not possible by limiting oneself to specific signals on the lexical level, the political discourse "presupposes the appreciation of its background, the expectations of the author and the recipients, concealed motivation, preferred ideas and logical procedures typical for a particular time" [6]. In the analyzed texts we are able to observe certain linguistic stereotypes stemming from language strategies effectively targetting the addressee. Language stereotypes such as semantic preference of a given language or communication strategies such as society's value criteria [6] can be misused for political purposes with the help of radicalized purpose-built texts, when the author knows the addressees and their current fears and frustrations stemming from social-economic situations.

LSNS - a party of right-wing populism - adopts its own attitudes in political discourse with the help of a communication strategy based on the principal of opposing dichotomy (compare Štefančík - Lid'ák) [5]. In the so-called high politics in the parliamentary elections of 2016, the party focused on the opposing relationship between an external enemy and domestic citizens. The texts personified the external enemy as Brussels and the EU as well as NATO. Posters and billboards spread fear arriving from abroad. They hint at possible attacks of foreign ethnicities or nationalities that are not able to know our culture, traditions and way of thinking and may disrupt the national and ethnic integrity of the Slovak nation - this rhetoric reflects the ideology of nationalism. At the same time the texts refer to financial dependency and bank usury at the expense of losing one's own self-sufficiency. The slogan "We are going to put Slovakia above the dictate of Brussels" became the main program point of the campaign in the parliamentary elections of 2018, during which the party's propaganda was built on the criticism of the external enemy based in Brussels as the main center of decision-making for the EU states. In this slogan, the word dictate can be marked as the main expressive-evaluating lexeme. Its evaluating parameter is: forcing, authoritative order or forcible command, pressure. In this case, the negative evaluating relationship towards Brussels as well as the EU in general is being manifested. The party's program statement extends this negative content: "The EU directives are even superior to the laws of the Slovak Republic." In this context the evaluating element of the word directives is authoritative. In this sentence the word even also has an expressive function, which emphasized the meaning of the word it precedes, it points to the higher degree of action, in this case the superiority to the laws in a negative evaluating sense of inappropriate, supercilious. Another protest against Brussels stems from the acknowledgement of bureaucracy in the Slovak Republic: "As a result of this bullying, hundreds of Slovak companies ceased to exist." Here, the colloquial word bullying (in the Slovak version, the word šikana was used, which is rather colloquial in comparison with the English bullying - translator's note) can be marked as the main representative of a specific lexis with a negative evaluating meaning of harassment. In this sentence the numeral hundreds, representing a large quantity, may also be labeled as emotionally charged, confusing, deceptive. The monolingual dictionary features the numeral hundreds with an expressive qualifier as it serves the purpose of referring to a nonspecific large quantity of something. In this case again, the use of this lexical unit (hundreds) becomes misleading, the same as the rest of the content. Many other texts are also based on quantitative expressiveness, e.g. "Today, we buy numerous overpriced products from abroad.", where the signal for vague quantity is the indefinite word numerous and the expressive colloquial word overpriced. The expressiveness of this word intensifies due to its quantitative element as well as through its negative evaluating component meaning excessive. The expressive evaluating component of quantity also appears in topics concerning external foreign enemies - the migrants: “... hordes of Muslim immigrants are rolling over you...", where the lexical unit hordes indicates an expressive colloquial word, which in today's informal communication represents a large number of people in one place. The etymology of this word, however, is rather interesting - originally it was a large group of former invading nomads or plundering raids, or in a metaphoric pejorative meaning a group of people performing violent, riotous or criminal activity. At this point, we may ask ourselves if the use of this word was purely accidental or, in fact, purposeful. According to co-authors Mikuš, Gurňák, Máriássyová current parties of the extreme right "utilize the xenophobic issue rather purposefully as so-called "popular xenophobia", where the emphasis is placed on harmony between the voters' mood and the issues of foreign elements, especially the issue of immigrants" [1].

The issue of the EU is tied to another text containing an expressive construction with a negative evaluating charge: "Brussels bureaucrats are trying to silence the criticism of the European Union by the fables about the EU funds." In particular, we are talking about the words silence by the fables about the EU funds, where the semantic meaning of the word silence bears a descriptive element of the meaning along with a synonymic descriptive component with a negative meaning: to forcefully keep quiet or not to allow to express oneself. This meaning manifests itself even stronger, more effectively, in connection with the word fable, which 
bears a negative evaluating element in an expressive metaphorical meaning of something untrue.

Another billboard slogan hinting at an external enemy is also: "It is high time for us to leave the EU!", which urges the recipient through expressive evaluating construction high time. In the Slovak language the phrase actually contains the superlative form of the adjective high (it is the highest time), which suggests a large value, degree and in connection with the word time it has a descriptive component of syntagmatic connection with the meaning of absolute, supreme or ultimate to the highest degree, there is no space-time for other solution.

In the rhetoric of LSNS, the basic communication principal of right-wing populism - the opposing dichotomy is aimed also at an internal enemy. It is achieved on two social levels: the first is represented by the oligarchs and the ruling politicians frequently tied to the oligarchs, the second level represents the minority, mostly the Roma population. The language stereotype aimed at the expressive semantics of the content is frequently utilized by LSNS in both the parliamentary as well as the communal elections. The representatives of L'SNS made use of the anti-Roma issue and "their own medialization in connection with the Roma problem (visits to problematic locations, etc.)" [1] for the formation of their simple electoral program as early as the communal elections of 2013. The internal enemies represented by leading government officials including the head of state - the president of the Slovak Republic - are presented through a significant lexis which expressively articulates radical disdain of authorities and democracy - this ideology has its roots in Fascism and Nazism [7]. To clearly distance themselves from this group, the right-wing extremists use personal pronouns: "We are not lead by the craving for money and power!!! YOU CREATED US!!! We are a response to your treason, crimes and embezzlement. We are the Kotlebas!!!" (Marián Kotleba is the leader of LSNS the translator's note). Here, we can clearly observe the opposing relationship of US (we) versus THEM (you, your). The signal of the pronoun also appears in the name of the party itself - LSNS, Our Slovakia. Distancing themselves from the activities of others by using pronouns is fortified by expressive words with negative descriptive components: treason, crimes, embezzlement, which are directly mediated to the addressee - voter - without the need for euphemization. They are accusing the current government system lead by the president of these crimes and betrayal of the nation. It is obvious from the content of the text as well as from the imagery. The contrast of colors points to a negative and positive division of society. In this case, too, the representatives of LSNS take up the role of the nation's saviors as they are going to destroy the current non-functional system, this is suggested by crossing out the current politicians.

Populism appears in the language of right-wing extremists rather often and in various forms. It is markedly present in the lower politics, on the level of districts in communal elections. When directed towards common people and the nation, the above-mentioned medium of opposing dichotomy is utilized (US - the locals vs. THEM - the foreign, which can refer to all minorities in general as well as the migrants, or US - the good vs. THEM - the bad - the politicians in power) or the interest in people is manifested without this dichotomy. The rhetorical figure of synecdoche is another stylistic language element, which the populists use to refer to the better part of the nation - the people who support the program priorities of the party, while others are considered enemies [8]. For stronger effect, the language of populism is supported by imagery, depicting the most sensitive and vulnerable members of society - children and retirees - in the presence of LSNS representatives presenting a material or financial gift. Depicting the charismatic leader, who is able to win over the masses, is another basic pillar of populism utilized by LSNS - it's leader Marián Kotleba is present in the party's name as well as on various images. In the pre-election program of 2016 the strategy of aiming at Slovak people became very strong. In addition to the above-mentioned rhetorical figure of totum pro parte, the party utilizes an effective rhetorical figure of topos. This figure focuses on the requirement of people representing the nation's majority, who are connected by the same socio-economic status and whose appeals should be heard, fulfilled. The slogans on billboards and posters contain catchwords like: We are going to establish a just social system! This slogan is dominated by the evaluating meaning just without the descriptive component, to which the entity social system is assigned in the context. By assigning this positive characteristic to the entity social system, the general awareness of social system is being updated. In today's Slovak society it is generally considered unjust. Addressing the target group of voters can also look like this: We are going to set the age of retirement to be 60 ., We are going to increase the maternity benefit to $100 \%$ of the mother's salary. We are going to extend the drawing of maternity benefits to 3 years. We are going to give a chance to decent families to obtain a rental flat. We are going to set up interest-free loans for newly-weds. Although these slogans address particular recipients, they lack deeper explanations or concretizations of the party's visions or arguments. Therefore, the language of populists becomes generally more effective in that socio-economic group which manifests no interest in verifying the authenticity of such slogans or catchwords. That is why the representatives of right-wing populism like to present themselves in a written form; in this way they can target and fascinate their audience via thought-out strategies much more efficiently.

Orientation towards common people in the language of populism is sometimes realized even more aggressively: "While decent people must make a living by working, Gypsy extremists get everything for free - housing, social and other benefits." This sentence contains a typical strategic tool for creating texts of language populism - the opposing dichotomy based on the opposing pair: the good = Slovak people vs. the bad = the Roma minority. Linguistic means attempting to achieve expressivity which aims at the addressee's emotions are: contrast (decent people - Gypsy extremists, making a living by working - getting things free) and evaluating emotionally charged words (decent, Gypsy). This hateful aggressive language strategy stems from the ideology of nationalism characterized by internal homogeneity (nation without foreign elements) and external separation (differentiation from surrounding nations and 
protection against external influences - e.g. globalization, interference of other states) [1].

The second topic of communication used by right-wing populists is the Roma minority. The aim of this communication is to induce negative evaluating relationships towards a foreign element in the Slovak population. This type of political discourse is utilized by right-wing populists in regional as well as nationwide political rhetoric. In the Slovak parliamentary elections of 2016, the following texts appeared on billboards as well as in the program statement of LSNS: We are going to take care of the thieves in ties as well as the parasites in settlements. The whole statement is aimed at both internal enemies - current government officials as well as the populous Roma minority living in Slovakia. Both syntagmata representing these entities - thieves in ties and parasites in settlements - are characterized by their evaluating element of meaning. The evaluating component in the phrase thieves in ties is quite apparent as it is defined through affectively evaluating lexical meaning reflecting a high degree of emotional experience. This lexis is presented mainly through cusswords or vulgarisms and according to co-authors Orgoňová and Bohunická the function of these lexical units is to express intense negative or positive emotional reaction towards the personality or behavior of another person [4]. In connection with the word ties it directly refers to people in the official public sphere while together the words act in contrast: the tie as an expression of noblesse, fancy, seriousness - the thief as a representative of an inferior community, as a dishonest person profiting at the expense of others. On the contrary, in the phrase parasites in settlements the emotional evaluating component is only implied and it is a result of transferring the meaning (figurative meaning) and applying an intellectual evaluating component [3]. It means that the emotional negative component itself is achieved secondarily based on knowledge of reality - parasite and based on knowing the characteristics of such a life form, he/she evaluates parasitism. This transferred characteristic is then attributed to persons living in Slovak settlements - thus to Roma people. In the expression the syntagma take care of is optically superior (the personal pronoun WE is omitted in the Slovak version of the text). The authors of the text apply the basic principle of right-wing populism in communication, which is distancing themselves from others by using personal pronouns. The construction in the form of a phraseological unit with a descriptive component to discipline bears in addition to intellectual evaluating component also the emotional stable evaluating component of "sorting out something or someone bad, disorderly", which is strengthened in contextual expressivity in connection with other components of the text [9]. This linguistic strategy is especially effective in the elections as the voters feel various economic-social frustrations in society, which they blame on ruling parties or individuals. These frustrations are also connected with the inactivity of the ruling politicians concerning the problematic minorities and their apathy towards protecting the interests of the majority. At the same time the slogan offers solutions (albeit vague and misleading) in the form of a conventional phrase with a radical evaluating meaning. Strongly expressive evaluating expressions indicating the Roma population also appear in the non-election contributions of the LSNS representatives. In the extracts of some statements we can observe the frequently used opposing principle of communication: "In the middle of this working week asocial persons broke into the house of a disabled retiree in Tisovec." (LSNS, 2018) The opposing rhetoric can be observed in using the contrasting connotation of: asocial persons $\leftrightarrow$ disabled retiree, where the asocials are specified by using a colloquial word in plural with a descriptive meaning. The negative evaluating component is part of the meaning with a descriptive and evaluating component - parasite - , and on the other hand the retiree is depicted as a respectable member of society while his weakness and vulnerability is strengthened by a descriptive meaning with an indefinite evaluating meaning of disabled (retiree). The following text also evokes negative evaluating charges, which are achieved by inherent or adherent expressivity: "Such unbelievable audacity and brutality of the asocials are a result of the police inactivity and a lack of interest of politicians from standard parties (SMER, SNS, MOST-HÍD, OL'ANO, etc.), who focus only on their own racketeering." The meaning of the word audacity contains a descriptive component with a negative evaluating characteristic temerity, which is intensified by the adjective unbelievable characterized by a meaning of a word with very large size or intensity that in this phrase functions as an effective evaluating expression in the form of an intensifier. The phrase brutality of asocials bears two obvious descriptive meanings with a descriptive as well as evaluating components with negative evaluating charges: crudeness and parasite. The derivative words of opposite meaning inactivity, lack of interest contain a negative assessment of the police and politicians. These are words with evaluating meanings without a descriptive component that expresses the evaluating relationship (passive or indifferent, impassive), but does not inform the recipient about the characteristics of entities being assessed. In the political discourse of L'SNS the expression standard parties is used with an aim of pointing to the descriptive component of the adjective standard corresponding to the standard, norm with unspecific evaluating component, while in connection with the word party it refers to current ruling parties. This particular phrase "expresses a clear distancing from existing political parties" [5]. In this text the word standard is exemplified, but it often appears in speeches of right-wing populists without an identifying charge, the identification of the expressions standard politicians, standard political parties occurs through other political discourse that points to dichotomic bipolarity of WE the good and THEY the bad. In this case the neutral descriptive meaning of the lexeme standard becomes contextually expressive with reference to the end of the sentence containing the phrase they focus on their own racketeering, in which the lexeme racketeering is pre-marked with a strong inherent evaluating component, because this phrase contains meanings with strongly implicated evaluating components, which is being deciphered through secondary transferred meaning due to emotional evaluating components with a pejorative meaning: totally dishonest activities.

The negative evaluating phrase asocial parasite and the 
word asocials appeared 8 times on a relatively small space of the article from which our sample text comes. This can be marked as a targeted utilization of the stylistic expressive means of repetition with an aim of increasing the propaganda effect.

In connection with the negative political rhetoric representatives of L'SNS distance themselves from a third internal enemy - the mainstream media. The language strategy is clearly chosen to differentiate the followers from supporters of current non-functional socio-political systems in Slovakia. "When a roughneck killed Henry from the Philippines in Bratislava, the mainstream media went berserk But when asocials brutally kill a "common" pensioner, the media are quiet." The populists refer to their own media as an alternative option, which exposes the truth. In an analyzed contribution from social networks - this is the main promotional media of LSNS -, as is the case in other official contributions, the party sets itself apart from activities of domestic enemies by utilizing bold font and it comes up with its own populistic solution on behalf of the domestic population: "We are, however, not going to remain quiet, because the life of a brutally killed retiree is as valuable as the life of anyone else. In reaction to this terror LSNS is preparing a hard counterreaction." (L'SNS 2018) This political discourse of right-wing populists reacts to current problems in society, while they distance themselves from the non-functional system and take on the role of people saviors. A typical sign is to refer to the interests of people and the nation (as is documented by the reference to one representative of the nation - the retiree), for which they use either an aggressive militaristic vocabulary from the ideology of fascism such as hard counterreaction or they use words referring to higher forces like God, Christianity or the Church. In pre-election leaflets and posters and on billboards individual representatives of L'SNS often refer to the slogan For God and for the Nation!, while the word God appears in various orthographic modifications beginning with either small or capital letters. As they identify with the Christian designation of the supernatural being, the word God should be uniformly written with a capital letter. Connecting various activities with Christianity in general is a popular means of intensifying the populistic manipulating effect among people We are going to base the education of the youth on traditional national and Christian values. The right-wing extremists place liberalism against this ideology. Liberalism is identified by denominations with expressive content with a negative evaluating element: perversities and indecency in the media, registered partnerships and adoptions of children by perverts, degenerated society. Preference of conservativism or traditionalism in the rhetoric of the right-wing parties also means favoring nationalism or patriotism, regionalism and authoritarianism, which fall under the characteristics of right-wing populism [10].

In the last district elections of 2018, the rhetoric aimed at the current ruling system and the external or internal enemy became the main topic of LSNS slogans: Resistance against corruption and financial groups". Moral distancing of L'SNS from the current internal enemy is being presented via the word corruption. Its semantic description contains a descriptive component representing a negative evaluating characteristic of bribery, boodling. The evaluating meaning of this lexeme is tied to another component of this slogan financial groups. This syntagmatic connection is emotionally charged in style, where it may be placed in the category of literary words, or in particular in the category of economic terms (def.: it is a group containing more financially strong individuals, representatives of the financial oligarchy as well as certain companies, concerns and trusts). In regards to financial power the term financial groups generally associates with an expressive phrase financial sharks, but often also with neutral words like international, active, etc. The strategy to use this expression in the LSNS slogan is not accidental, the objective was to utilize the negative medialization of scandals connected to the oligarchs and financial concerns linked to the current political scene. Bridging of the phrases corruption and financial groups can be considered strongly charged based on the evaluating meaning with a descriptive component baring a negative undertone. A similar damnatory signal against the internal politics is implied by the billboard slogan: With Courage Against the System! The semantics of the word courage contains a positive evaluating meaning without a descriptive component pointing to the evaluating relationship only, but the rest of the context clearly implies what characteristic of the lexeme system it refers to: courage to fight with the current badly functioning system, by utilizing the stylistic figure of contrast. Also, the main message of the election poster: WE WON'T LET YOU DOWN! points to the semantics of the word disappoint containing a negative evaluating component "to not fulfill one's expectations" or "to acquit oneself ill" or just ,to prove to be insufficient". By implying a double negation - the verb with a negative evaluating component in its meaning used in a negative form - bears a reference to the preceding ruling system, which brought disappointment. The slogan from the regional elections of 2018: "The Time of Big Changes Has Come!" reflects a new indefinite vision. It is not possible to derive any negative connotation from the meaning of the word changes, the reference to the second meaning of this poly-semantic word: "to substitute something, somebody by someone else (of the same type), to replace" is, however, quite strong. The presence of such a description of meaning, which is hyperbolized by the adjective "big", refers to the current government that is going to be replaced soon, as is suggested by the expression "the time has come". This phrase may be viewed as a synonym to the "it is high time" with the meaning "it is necessary to act". As a phraseological unit with a figurative meaning this expression, then, may be considered expressive or emotionally charged.

\section{CONCLUSION}

The language of extremism or right-wing populism is characterized by typical signs from the point of content as well as form. Depicting contemporary topics in a form of dichotomic opposition seems to be particularly effective with the Slovak population as well. The form of a simple linguistic depiction enriched by an emotionally charged evaluating lexis sounds as if it was a voice of a common Slovak citizen. Communication impact and the emotional experience of 
individuals is in the case of LSNS an effective strategy proven by the successes in the parliamentary elections of $2016(8.4 \%)$. This strategy is effective in gaining voters, but if it brings no real actions, it doesn't bring such gains later on. The success is short lived. The result is the drop in preferences for LSNS only two years after the parliamentary elections and five years after regional elections (evidenced by the regional elections of 2018).

\section{ACKNOWLEDGMENT}

This contribution was prepared as a part of the project APVV 17-0128 06K1119.

\section{REFERENCES}

[1] R. Mikuš, R. D. Gurňák, and A. Máriássyová, "Analýza volebnej podpory Mariána Kotlebu ako reprezentanta krajnej pravice v krajských vol'bách 2013,” Sociológia, pp. 48-70, vol. 48, 2016.

[2] J. Hasil, "Jazyk české publicistiky jako odraz českého politického diskursu?," in Sociolingvistica Slovaca 7, Jazyk a diskurz v kultúrnom a politickom kontexte, S. Ondrejovič, Ed. Bartislava: Veda, 2013, pp. 60-67.

[3] J. Dolník, Lexikológia, Bratislava: Univerzita Komenského, 2007.

[4] O. Orgoňová and A. Bohunická, Lexikológia Slovenčiny. Učebné Texty a Cvičenia, Bratislava: Univerzita Komenského, 2011, pp. 254.

[5] R. Štefančík and J. Lid'ák, "Priatel' a nepriatel'. Jazyk pravicového populizmu," in Jazyk a Politika. Na Pomedzí Lingvistiky a Politológie II., Bratislava: Ekonomická univerzita, 2017, pp. 473-483.

[6] I. Dulebová, "K otázke definície pojmu politický diskurz," in Sociolingvistica Slovaca 7, Jazyk a Diskurz v kultúRnom a Politickom Kontexte, S. Ondrejovič, Ed. Bartislava: Veda 2013, pp. 45-51.

[7] R. Štefančík, "Politický jazyk. Ako ho definovat?," in Jazyk a Politika. Na Pomedzí Lingvistiky a Politológie, R. Štefančík, Ed. Bratislava: EKONÓM, 2016, pp. 28-46.

[8] R. Štefančík and I. Dulebová, Jazyk a Politika. Jazyk Politiky v Konfliktnej ŠtruktúRe Spoločnosti, Bratislava: FAJ Ekonomickej univerzity v Bratislave, 2017.

[9] J. Zima, Expresivita Slova Vsoučasné Češtině. Studie Lexikologická Astylistická, Praha: Nakladatelství Československé akademie věd, 1961.

[10] C. Mudde, Populist Radical Right Parties in Europe, Cambridge: Cambridge University Press, 2007.

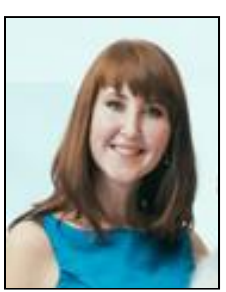

of Education.

Her current scientific research at the department is directly related to her pedagogical work. In the field of science and research she deals with the study of the relationship of language and culture on the lexical and stylistic plane, the syntactic plane, the history of the literary Slovak, the didactics of the Slovak language as maternal and foreign languages.

She has written a lot of working papers and published 2 monographs and tree handbook concerning Slovak linguistics, pragmatics and sociolinguistics of Slovak language

Zdenka Kumorová is an assistant professor of linguistics at the Department of Slovak Language and Literature at Faculty of Arts of University Ss. Cyril and Methodius in Trnava from 2009 to the present. She was born in Martin, Slovakia, December 9th, 1982. obtained her master degree on lingusitics from Faculty of Arts of University Ss. Cyril and Methodius, Trnava in 2006 and accomplished her doctorate Trnava in 2006 and accomplished her doctorate (n) . 